\title{
'I was a Girl of my Time’: A feminist literary analysis of representations of time and gender in selected contemporary South African fiction by women
}

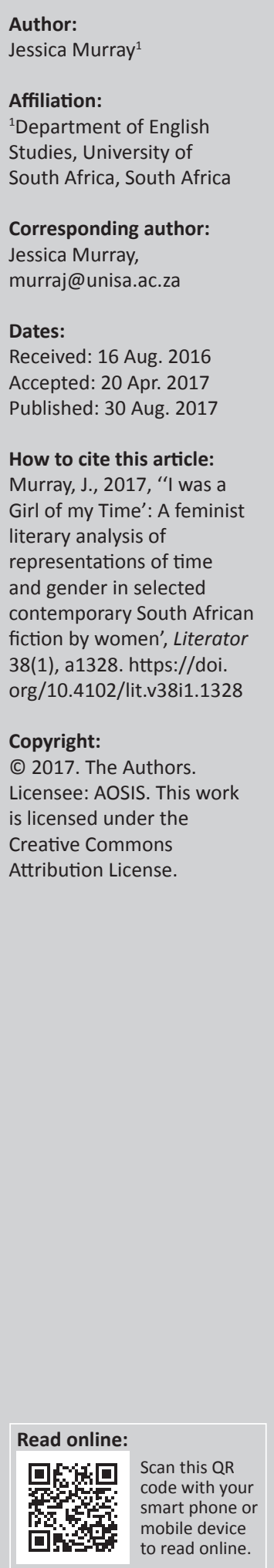

This article offers a feminist literary analysis of selected contemporary South African texts by women writers in order to explore how they represent female characters' engagement with conventional understandings of time and its chronological and linear progression. These engagements are represented as being particularly fraught for women characters as they find themselves constrained by various temporally located constructions of femininity even as they attempt to heed the temporally dislocated voices of gendered trauma that consistently speak through their bodies. In this article, my focus will be on Bridget Pitt's novel, Notes from the Lost Property Department (2015), Elleke Boehmer's The Shouting in the Dark (2015) and Mohale Mashigo's The Yearning (2016). Despite frequent references to the importance of temporality in making sense of the experiences of the female protagonists, there has been a dearth of scholarly attention to the complexities of the intersections between gender, time and trauma in contemporary South African fiction by women. While gender violence and trauma are topics that have received extensive critical scrutiny in South African literary studies, this article demonstrates that the inclusion of temporality in the analytical framework enables a richer and more nuanced reading of the experiences of the female characters in the selected texts.

'Ek was 'n Meisie van my Tyd': 'n Feministiese literêre analise van uitbeeldings van tyd en gender in gekose eietydse Suid-Afrikaanse fiksie deur vroue. Hierdie artikel bied 'n feministiese literêre analise van gekose eietydse Suid-Afrikaanse tekste deur vroueskrywers om te ondersoek hoe hulle vroulike karakters se omgang met konvensionele insigte oor tyd en die kronologiese, liniêre progressie daarvan uitbeeld. Hierdie omgang word uitgebeeld as besonder belaai vir vroulike karakters omdat hulle beperk word deur verskeie tydsgebonde konstruksies van vroulikheid selfs terwyl hulle poog om aandag te skenk aan die tydsontwrigte stemme van gendertrauma wat herhaaldelik deur hul liggame praat. In hierdie artikel is my fokus op Bridget Pitt se roman, Notes from the Lost Property Department (2015), Elleke Boehmer se The Shouting in the Dark (2015) en Mohale Mashigo se The Yearning (2016). Ten spyte van gereelde verwysings na die belangrikheid van temporaliteit in pogings om die ervarings van vroulike protagoniste te verstaan, is daar 'n tekort aan akademiese aandag aan die kompleksiteite van die snypunte tussen gender, tyd en trauma in eietydse Suid-Afrikaanse fiksie deur vroue. Alhoewel gendergeweld en trauma onderwerpe reeds wye kritiese aandag ontvang het in Suid-Afrikaanse literêre studies, wys hierdie artikel dat die insluiting van temporaliteit in die analitiese raamwerk 'n ryker, meer genuanseerde lesing van die ervarings van vroulike karakters in die gekose tekste moontlik maak.

\section{Introduction}

According to Odih (1999:9), '[r]epresentional linear time is premised on the rational ordering and control of space and time and the denial of différence; it knows no Other'. Because women and their experiences have traditionally been relegated to the discursive space of the Other, this means that time and temporality are issues of grave concern to feminist theorists. Apter (2010:4), for instance, explores how Julia Kristeva's work on 'women's time' calls for a 'feminist recuperation of archaic and futural temporal measures: cycle, period, pregnancy, the creative time of aesthetic practice'. At an even more obvious level, time is important to feminist scholars because gender is always already a temporally contextualised social construction. Butler (1990:140) reminds us that 'gender is an identity tenuously constituted in time'. Finally, the traumatic experiences of the female characters in the selected novels make it all the more necessary to consider alternatives to 
rigidly linear conceptualisations of time. This paper employs some of the most important feminist interventions in understandings of and assumptions about gender and time to offer a feminist literary analysis of Bridget Pitt's novel, Notes from the Lost Property Department (2015), Elleke Boehmer's The Shouting in the Dark (2015) and Mohale Mashigo's The Yearning (2016). In these contemporary South African women's texts, references to time, and to women's experiences as temporally embedded and constrained, abound. In all three texts, the female characters find that the past bleeds into the present as secrets emerge and memories erupt into the present and, in doing so, they threaten to disintegrate the sense of a unified self. In my analysis of Pitt's text, I will focus on the representation of the relationship between the character of Iris and her aging mother Grace. The author attempts to disrupt a conventional linear narrative pattern to articulate the experiences of these two characters, and she invites the reader to consider how normally othered aspects of experience are central to their lived realities. Boehmer's protagonist, Ella, struggles to develop a coherent sense of her place in the world to amidst her father's misogynist and racialised denigration of her mother and dictates of how a 'natural' woman of her time should enact femininity. In the case of Mashingo's novel, the temporal dislocation that is associated with trauma serves to demand a more creative engagement with time. By analysing these three texts together through a theoretical framework of feminist engagements with gender, time and temporality, the article will shed light on the extent to which women's experiences continue to be shaped by temporally and spatially located constructions of gender and how trauma insists on disrupting conventional understandings of time.

\section{Gendered trauma and time}

Towards the end of The Shouting in the Dark, after starting to come to terms with the various gendered and racialised traumas that characterised her childhood, Ella articulates the inadequacy of a linear understanding of time as follows:

The world is all before her, but time, as the Greeks have told her, doesn't always run forwards in the smooth way you might expect. Unanticipated reminders can bring sudden loopbacks, interrupting the plain surface of things. Knotholes surface in the wood; one story fails to branch into another. (Boehmer 2015:257)

Ella's observations call to mind the work of numerous scholars who describe how traumatic experiences involve a 'disruption of the temporal sequence of instants' (Derrida 2000:75). Caruth (1995) articulates the difficulty of articulating trauma as follows:

trauma is not experienced as mere repression or defence, but as a temporal delay that carries the individual beyond the shock of the first moment. The trauma is a repeated suffering of the event, but it is also a continual leaving of its site. (p. 10)

Fiction opens up spaces in which such traumatic events can be articulated in ways that 'register, in the form of its language, the gaps in memory and logic that thwart narrative coherence and linear chronology' (Kennedy \& Jan Wilson
2003:125). Trauma studies is a field that has received wide scholarly attention across the globe. Meinig, for instance, theorises trauma in the context of Australia's stolen generation, and she describes trauma as the epitome of the final inaccessibility of an event in the past and the latency of its interpretation' (2004:350). Kilby (2002:205) explains the implications of the inaccessibility of the traumatic event as follows: '[i]n a sense, therefore, there is nothing to remember except perhaps a sense that there might be something to remember'. Berger (1997) theorises the representational and temporal challenges that trauma poses and he posits that:

[i]n its emphasis on the retrospective reconstruction of the traumatic event (for the event cannot be comprehended when it occurs), a traumatic analysis is both constructivist and empirical. It pays the closest attention to the representational means through which an event is remembered and yet retains the importance of the event itself, the thing that did happen. (p. 572)

Laub (1992:57) is another important trauma theorist who argues that a traumatic event is experienced as an 'overwhelming shock' rather than as something that can be integrated seamlessly into the victim's frames of references. He expands on this point by explaining that:

traumatic event, although real, [takes] place outside the parameters of 'normal' reality, such as causality, sequence, place and time. The trauma is thus an event that has no beginning, no ending, no before, no during and no after. (p. 69)

\section{According to Murphy (2006):}

[t]rauma's interstitial residence in the memory gives rise to one of the greatest difficulties in treating trauma. On the one hand, the traumatised subject needs to testify to his experience and achieve some mastery over it in the form of narrative, but to turn the catastrophe into just another story is to deny its power, because narrative's structure denies one of trauma's most salient features - its resistance to form. (p. 59)

All these challenges related to the very nature of trauma help to account for the fact that experiences of trauma can so easily be elided. As Felman (1992) notes:

[b]ecause our perception of reality is molded by frames of reference, what is outside them, however imminent and otherwise conspicuous, remains historically invisible, unreal, and can only be encountered by a systematic disbelief. (p. 103)

In the South African context, in Narrating our Healing: Perspectives on Working through Trauma, Van der Merwe and Gobodo-Madikizela (2007) offer important insights into the dynamics of trauma when they explain that:

[m]emories of trauma are not encoded in the same way as normal experiences. They are stored in dissociated and fragmented form, and often dominate the mental life of victims of trauma. (p. 25)

In terms of the temporal issues related to trauma, Van der Merwe and Gobodo-Madikizela (2007) argue that, for victims of trauma:

a crucial matter is the abyss between the time before and after the trauma, an abyss that has destroyed all feelings of continuity and order, and they need to include the abyss in their story. (p. 6) 
Although there is no one single violent event in Ella's story that can be identified as traumatic in any straightforward way, a close feminist analysis of the text reveals repeated instances of gendered so-called microaggressions as she was growing up, and the cumulative effect of these can certainly be regarded as a traumatic, discursively and epistemically violent assault on her identity as a girl child and later as a young woman. In her classic feminist text, Misogynies, Smith (2013 [1989]) explains that misogyny 'isn't just hatred or fear of women, although both these emotions are involved, but a whole series of slighting and dismissive attitudes'. Nadal et al. (2013:193) note that, '[i]n recent years, the study of microaggressions has emerged in the fields of psychology and education' and gender microaggressions 'are defined as brief and commonplace verbal, behavioural, and environmental indignities that communicate hostile, derogatory, or negative slights and insults toward women' (p. 193). The researchers identify a range of short and longer term consequences of 'the cumulative nature of these types of microaggressions', amongst which they list trauma. Similarly, Berg (2006:970) examines the 'correlations between everyday (nonviolent) sexism and the development of trauma symptoms in women' and she finds a 'moderately strong relationship' between the two. ${ }^{1}$

Although both Ella's parents are themselves profoundly damaged individuals, my analysis will focus on the traumatic impact their gendered aggressions have on Ella and how these experiences leave her with a story that refuses to be slotted into a simple linear narrative, as she describes above. Ella explains how her parents constitute a team in order to highlight her various 'defects'. Her mother focuses on the inadequacies of her body whereas the 'father mostly keeps quiet on the subject of Ella's physical defects. Instead, it's her character that concerns him' (p. 26). This gendered division of labour places the family very firmly in a patriarchal epistemological framework where the damaging Cartesian logic of the body or mind division reigns supreme with women being associated with the former and men with the latter. Ella articulates these thoughts as a 9-year-old girl and, in their formulation, it is clear that she has already accepted her mother's opinion that her body is somehow defective. The specific bodily phenomenon that is concerning her mother at this early stage of the novel appears to be a perfectly natural vaginal discharge (p. 23) that is used to shame Ella to such an extent that she 'tries to imagine she's invisible' (p. 25). The rest of the novel will demonstrate that it is her feminine identity rather than her character that is her father's primary concern.

Despite the undeniable shortcomings of her mother, the gendered dynamics in their home reveal her father to be a misogynist patriarch whose rage is directed at both Ella and her mother. During an incident, that is, sparked by Ella's mother burning a meal (p. 73), the father exposes both his

1.Although everyday sexism and gender microaggression are obviously closely related phenomena, the most recent literature on microaggression distinguishes between
the two. For useful information on the nature and importance of this conceptual the two. For useful information on the nat
difference, see Nadal et al. (2013:193-220). deeply embedded hostility to women and his notion of what their 'proper' feminine role should be. He asks his wife 'When will you women ever get it right?' (p. 73) and he expands the verbal assault to include Ella when he asks 'What earthly use do you people have?' before calling them 'succubi ... sucking the lifeblood from [his] veins' and offering the following observations of what he expects from women: 'It beats me utterly. That you women can't get right even the few things you're good for. Like homemaking maybe. Like maybe giving a man an embrace' (p. 74). In his gendered worldview, women's proper roles thus include the very traditional roles of homemaking and providing physical comfort and affection to men. Like Ella's earlier attempt to hide away and take up as little space as possible in the doctor's rooms, her mother responds to the attack by whimpering and leaving the room (p. 73). These rages that see the father literally frothing at the mouth with 'white spittle gathering in the corners of his mouth' (p.74), come out of nowhere and Ella seems to grow up in a constant state of alert against attacks on her gendered being. Later in the novel, the author describes how Ella 'goes to set the table as usual. She senses the father suddenly turn in his chair to face her' (p. 126). An act as unremarkable and everyday as setting the table prompts the following outburst from her father:

Look at her, he says in his loud voice, Gawping like some native. Or no, not like a native, a native's too good. Like a woman, a witless woman. Drinking it all in as if there wasn't a brain in her miscast skull. (p. 126)

Ella is never in any doubt that the 'problem' her father identifies in her character can be traced back to the fact that she inhabits the world in a female body. In a rare moment of imagined connection, she 'remembers how the father nodded at her ideas as if she were a man, a proper grown-up' (p. 129) [emphasis added]. For her father, full humanity is clearly reserved for men. The extent to which he dehumanises Ella because of her gender is even more explicit when he tells her: 'What a fool I was, thinking a child of your mother could forget its weasel nature' (p. 149). In order to win her tormentor's favour, Ella tries her utmost to show her father 'what a rational, useful man she can be' (p. 160) [emphasis in original] but she inevitably falls short in this regard. He makes sure to continue Ella's tuition in his essentialist, misogynist view of women when he explains to her that soon 'boys will start to overtake [her], on almost everything' (p. 193), and certainly in the things that matter. In the end, he simply concludes: 'You'll no longer do as well as them'. This, in his view, is 'what nature dictates' (p. 193). He reiterates his belief in the Cartesian duality and women's relegation to the sphere of corporeality when he notes: 'Mark my words, as boys grow up, their brains better their bodies, overcome them. For girls it's the other way about' (p. 194). As if his comments were not disempowering enough, he insists that any attempt on Ella's part to challenge her oppressed status as a woman will simply make matters worse. When she tries to defend the value of her own opinions, he reacts as follows:

I'm telling you to rein it in ... Don't denature yourself, that's what I'm telling you. Act the young woman. Perversity isn't attractive. Splitting hairs, scoring points, and then in that horrible 
chainsaw voice, it's not attractive. Don't be an unnatural woman, hard and unforgiving, like many women in your mother's family. Don't go resenting men for the qualities that make us who we are. (p. 195)

As an only child and with a dysfunctional relationship with a mother who is herself abusive, Ella feels her isolation keenly and she has no real opportunity to gain other views about the purported inferiority of women that those her father offers. One day, however, it occurs to her that she can indeed connect with previous victims of his misogynist rage who are separated from her by temporal divisions:

The thought comes to her from nowhere: she's not the only one. She's not the first to be confronted by him in a rage like this, on her own. She's not the first in her father's life to quail inside like she's doing right now ... The other wife he sometimes mentions ... or the woman he says abandoned him, she's not sure, the wife or wives before her aunt, back in Singapore, Edit, Nancy Leong - she, too, every one of them, must have sat like this, trying to keep her shoulders square even as the blowtorch of his anger burned white places in her heart. (p. 128)

This ability to identify with other survivors across time offers the first instance where Ella realises that she is neither alone nor necessarily doomed to the life allotted to her in her father's gendered worldview. This connection to women beyond her own time enables her to imagine a time when things will be different, despite the undeniable trauma and hurt in her present. After her father's death, Ella hopes that she can restore some linearity to her narrative as she focuses on her future, which she describes as a world that is all before her, while she looks at the crematorium chimney where her father is being cremated and says to herself: 'There you go, past tense, silent at last. I can follow my own interests now and your hatefulness won't prevent me' (p. 243). In her futile attempts to establish her linear chronology, she refuses to read her mother's weekly letters because she knows that they 'will hark back whereas she is moving forwards' (p. 258). She has determined that she will be '[l]ooking ahead, not back ... Tomorrow stretches wide before her' (p. 255). Since the death of her father, she feels that this impulse to move linearly forward will be realised naturally 'now that she doesn't have to go about clenched like a fist, ready at every moment to take up arms, do battle with her adversary' (p. 256). Her terminological choices here reveal that she experiences her battles with her father as a form of warfare and this helps the reader to understand just how traumatic she found it. She is confident that the 'fighter who was created by that fight has died in her, or at least crept to a place where she no longer hears it stirring' (p. 256).

The past, however, it too insistent a presence in her present to be so easily relegated to the past and she increasingly finds that she will need to negotiate with time differently as she moves into her future. The following description reveals how she attempts different engagements with time to find something that works for her:

Everything is water, everything flows. You never step in the same river twice. Life proceeds by number, in patters. If $x$ is $y$ and $y$ is $z$ then $z$ is $x$. All things are linked and proportionate to all other things. (p. 254)
These observations move smoothly from the interconnected, relational and fluid understandings of time that are associated with feminist conceptions of time to the ideas of rigid linearity and causality that are linked to masculinised notions of temporality. When she says '[t]here you go, past tense, silent at last' (p. 243), her words ring hollow as no past, especially not a traumatic one, can be muted. Much as she wants to believe that ' $[\mathrm{t}]$ hat life's now over' and that 'she can throw away the page' (p. 243), life does not proceed in a straightforward turning of pages because the previous pages emerge like a palimpsest on the current page. Towards the end of the novel, she imagines reconnecting with Phineas, a young black man who worked in their garden without the spectre of her father's racist and misogynist presence. However, even as she is trying to convince herself that the past can simply be paged over, she realises that 'father, everything he stood for, would always be in the way' (p. 245). Even in death, 'the father would be there, the third in their conversation' (p. 245). Ultimately, she concludes that she will need to come up with an approach that challenges the patriarchal logic of linearity and binary oppositions, both of which form part of the larger masculinised epistemological framework. Dead versus alive, past versus future, love versus hate and good versus evil are dichotomies that speak as poorly to her experience as chronological movement through time. In order to engage with the legacy of parents she both love and feared to move into a future suffused with 'sudden loopbacks' (p. 257) into the past, she needs to let go of the illusion that she can close the book on the past and more forward into a future unburdened by her memories of her father and mother. The reader is left with some tentative suggestions of such an alternative understanding of time in a brief, concluding chapter entitled 'Zigzag' where Ella starts toconsider '[d]ifferent patterns: zigzags, circles, continuations; not warring opposites' (p. 272). The last line of the novel also indicates that Ella will need to resurrect the fighter she thought had died but, although the origin of the fight can still be traced back to her father, this is a battle in which she is the active and powerful agent rather that his victim. After moving to the Netherlands where she was born, Ella finds that her father never registered her birth there so she has no legal right to remain. The novel's last words are spoken by the Dutch lawyer who is helping her with her bid to stay in the country when he explains that their next steps will be a 'question now not of your father's oversight but your own hard work. Your fight, in short, is by no means over' (p. 273). Although the lawyer is referring to her fight to remain in the Netherlands, his words are also apropos of her attempt to continue her life in the 'zigzags, circles [and] continuations' that will enable her to acknowledge her traumatic past while still having a future that offers more than the pain of her childhood.

\section{The voice of the body speaking across time}

The refusal of traumatic childhood events to remain silent or to allow survivors to relegate them to the sphere of the past also emerges vividly in Marubani's narrative in The Yearning. 
Neither a simple linear progression or a circular temporal sequence does justice in telling her story as she finds herself vacillating between a traumatic unremembered past and her present where she often feels 'drenched in now' (p. 22). From the very beginning of the novel, however, it is clear that Marubani is able to draw on a powerful resource that was not available to Ella, namely, a supportive network of female ancestors in the forms of her mother and grandmother, despite regular friction between the mother and daughter. She explains this as follows: 'I am blessed with matriarchs who hold their own even when the ground falls beneath their feet' $^{\prime}$ (p. 7). Even though Ella and Marubani are separated by their locations in very different contexts that are marked by race $^{2}$ and class, their life prospects as well as their traumatic childhood experiences are very much shaped by the fact that they are girl children in worlds that are structured according to profoundly unequal gendered power relations. After her father leaves the family to pursue his calling as a healer, Marubani is raised by her mother who enlists the help of her own father to care for the child and her brother while she goes to work. Marubani seems to have grown into a happy woman after a childhood with her beloved grandfather as she now has a career she enjoys, a boyfriend she loves, as well as an apartment and close friend she cherishes.

The reader starts suspecting that something might be amiss, however, when Marubani refers to a 'sudden dizzy spell' (p. 28) for which she cannot quite account even though she tries to write it off as a consequence of having skipped breakfast. By the time she heads to work, she is 'feeling a wave of nausea rising' as a 'melody creeps out of the corners of [her] mind and [her] heart jumps into [her] throat' (p. 30). She tries to make sense of the song as follows:

This is not a thought. It is not a memory. Nor is it something created by my imagination. It is the sound of children singing in my head as clearly as if I could pull them out of my brain and they would stand there, right before me in my office. (pp. 30-31)

She recalls her father warning her that the 'past and the future will stalk you', but advising her not to 'choose either of them, always choose today' (p. 31). Heeding his advice and remaining in the present, however, proves impossible, hard as she tries to do so: 'I try to immerse myself in my work but I can't concentrate' (p. 31). Her body continues to exhibit ever more severe symptoms to such an extent that she ends up hospitalised with doctors suspecting that she might have a brain tumour (p. 82). As she struggles to understand what is happening to her, her body speaks ever more loudly from beyond the confines of linear time or a chronology of past, present and future. Marubani explains that '[t]ime is suspended' (p. 100) as her 'body's voice guides [her]' and the 'body voice speaks and tells [her] to trust herself with the truth' (p. 100). The truth that finally

\footnotetext{
2.As in Boehmer's novel, references to racial dynamics abound in Mashingo's text. Although the former is set during the time of the Sharpeville massacre and the latter takes place in post-apartheid South Africa, the enduring legacy of apartheid continues to shape Marubani's present. While race and gender are intricately continues to shape Marubani's present. While race and gender are intricately
intertwined as markers of identity, for the purposes of this article I will be focussing intertwined as markers of identity, for the purposes of this article I will be
on the gendered dimensions of the characters' engagements with time.
}

emerges is that, as a child, she was abducted by the school groundskeeper who raped and beat her (p. 140). She is thus quite correct when she describes this as something, that is, 'not a memory' (p. 30) because it exhibits the 'temporal peculiarity' (Kilby 2002:206) that characterises trauma. Culbertson's (1995) explanation of this resonates strongly with Marubani's descriptions above:
... the violation seems to continue in a reverberating present that belies the supposed linearity of time and possibility of endings. It at once has a certain pastness, is a sort of 'memory-knowledge' ... and is not past, not 'memory' - that is, a personal, narrated account of something completed, locatable in time - at all. Perhaps it is not remembered, but only felt as a presence, or perhaps it shapes current events according to its template, itself unrecognised. (p. 170)

The singing children, whose songs Marubani could hear from the schoolyard while she was held captive, are felt 'as a presence' rather than a memory. Similarly, she senses such a presence when she 'glimpse[s] something moving at the edge of [her] vision' (p. 35), but she tries to convince herself that she just imagined it. Her body, however, keeps talking ever more loudly and she describes the following incident at her office:

Instantly my body tells me that something is wrong ...Then a big, cold hand falls on my shoulder... The hand dwarfs me instantly and a huge shadow is cast over me. I shut my eyes and breathe in deeply, telling myself that it's just an intruder and not the sinister stranger who was in the corner of my sitting room a week ago. (p. 61)

The image of a shadow evokes something that can only be present due to an absence of light. It is, like the memory of the traumatic childhood event, simultaneously there and not there. Kilby (2002:206) refers to the 'non-narrative or protomemories that beat away in [the] body' in the case of traumatic experiences. While Marubani's body continues to speak this unspeakable and unremembered past, it is clear that she needs to remember and to fit the experience into some kind of coherent narrative in order to approximate healing and to stop the seizure type events that render her incapable of functioning. Kilby (2002:206) explains that the 'promise of memory is premised on stripping traumatic memory of its specific temporality (which is what gives it its haunting ghostly power)...'. With the help of her mother and grandmother, Marubani confronts the abuse from her childhood and this allows her to resume a functional existence with her boyfriend as she herself becomes a mother to a little girl.

Feminist theorists have done important work on the ability of the body to speak both of repressed experiences and of the palimpsest-like inscriptions of gender on specifically located bodies. Bayer and Malone (1996:687) note that we are always 'faced with the question of locating the place(s) from which the body speaks' and they ask whether 'this place [is] simply defined as emanating from the voices of other women, from resistant readings of our own narratives, from regression therapy?' When asking these questions and engaging in these 
discussions about corporeality, they highlight the importance of temporality as follows:

\begin{abstract}
The notion of temporality introduced in the very idea of consciousness raising introduces at least a minimal wrinkle into this feminist encounter with the body. For if the body emerges through a certain reflectivity on the contradictions between past and present, it is neither a simple cipher of the social, a plaything of the patriarchy, nor a thing in itself to which we can return. Rather, the body exists at a certain interstice created by a temporal pulsation; the body is not a historical construction, it is the existence of historical contradiction. (Bayer \& Malone 1996:687)
\end{abstract}

Nowhere is this more strikingly apparent than in the case of the traumatised body. When Marubani goes through her initiation rite, her grandmother describes it as 'an important and necessary process' because she wants 'to make sure that [Marubani's] body and mind are speaking the same language' (p. 183). In helping her granddaughter in her journey towards womanhood, the grandmother is challenging the:

[s]eparations between mind and body and the hierarchical ordering of mind over body [that] haunt the history of western philosophical formulations of knowledge from Aristotle and Augustine through to Descartes and Kant. (Bayer \& Malone 1996:670)

\section{Femininity as temporally located construction}

The yearning to deal with unremembered childhood trauma, even as those events prove to be elusive in the present, as well as the burden of temporally located constructions of femininity that come to bear on the female body are also poignantly explored by Bridgett Pitt in Notes From the Lost Property Department. The narrative tells the story of Iris who suffered a traumatic brain injury during an unremembered childhood accident and who now has to care for her mother, Grace, who has recently had a debilitating stroke. As with Boehmer and Mashigo's texts, the author uses the first few pages of the novel to alert the reader to the fact that her female characters' experiences and the very existence are fundamentally shaped by structural gender oppression. In this case, it is Iris' sister, Jess, who articulates these pressures when she informs Iris that she will not be able to come home when they receive the news of their mother's stroke. She explains:

I just can't make it this time - you have no idea of the sexist bullshit I get from these male executives. They were totally opposed to the firm sending me on this course, and if I left now, it would just prove their insistence that women always put family before work. My job depends on this. (p. 14)

Jess, who is represented as a supremely competent and successful career woman, is thus placed in a position where the pressure to prove her worth in her job is so great that she is unable to take a few days off to care for her sick mother. As the novel progresses, the reader catches ever more revealing glimpses of how this gendered pressure that Jess is confronting in 2012 also structured the life chances of Grace in the previous generation. Grace recalls that she was only able to go to university after she got divorced and her 'children were grown up' because her 'father believed that it was a waste of time to educate a girl' (p. 75). When Grace talks about her granddaughter, Adji, she wonders at how different things are for women in the present in observations that gloss over the very real, albeit more subtle and insidious, work place gender discrimination described by Jess above. She explains that, Adji 'works for the UN in Geneva' and she marvels:

They make such glorious young women today ... Such boldness, such freedom from apology, such fearlessness as they march into the future. Girls of my day were not encouraged to fly too high, lest we startled our menfolk. (p. 131)

Grace's decisions regarding her partners were very much informed by her lack of other options and she admits that she first fell in love with a particular young man for the following reasons: '... because I was a girl of my time and men were our gateways to everything...'. (p. 186).

The limitations of Grace's options because of the prevailing gendered constructions of proper femininity when she was a young woman auger in the chain of events that eventually leads to Iris falling off a boulder during a family holiday in the Drakensberg in 1972. Much of the interactions between Grace and Iris over the course of the novel refer back to Iris's inability to remember the events on the night that she fell. In their thoughts and conversations, the notions of time lost, time unremembered and time running our repeatedly crop up alongside repeated reminders of what was expected of women in the various temporal periods that the novel covers. The text is divided into chapters and, just beneath the number and name of the chapter, the year is written in bold. The years in question are 2012, when Iris received word of Grace's stroke, and 1972, when Iris fell. Interestingly, some of the chapters are dated as '2012 - before'. These chapters narrate Grace's thoughts before her stroke. The addition of the term 'before' suggests an attempt by the author to impose some semblance of chronology onto the text even as it is disrupted by a narrative order that jumps between 2012, 1972 and '2012 - before'.

In one of the 2012 - before chapters when Grace still has access to her memories before the stroke, she recalls how she felt about Jeremy, an old boyfriend with whom she reconnects by chance during the fateful family holiday in the Drakensberg. She realises that her feelings may be the result of a 'middle-aged fantasy grafted onto some rosy-hued memory of young love' and she admits that she and Jeremy 'did not have the luxury of long years, of testing [their] love with time and misfortune' (p. 107). Yet, when they are together again after all the years of separation, she 'felt timeless and extraordinary' (p. 107). Once again, they are unable to be together, this time because she needs to take care of Iris after the accident, for which she blames herself. By the end of the novel we learn that Iris saw her mother and Jeremy kissing while her father was asleep nearby and that she fell after 
running off in the dark. After the brain injury that resulted from the fall, she cannot remember what caused her to run off alone and this only adds to Grace's sense of guilt. Even as she is afraid of doing so, Grace is desperate to tell Iris the truth and she thinks '[o]h. that we could unravel time, and reknit our lives without those ragged holes of omission and deceit' (p. 185). Her tortured reflections reveal how centrally the notion of time is here:

The best I can do is to tell her now. My mind freezes every time I try to imagine this conversation ... I must tell her - time is running out for me ... How do I find the words that I have spent forty years hiding? (p. 185)

When she is trying to figure this out, she wonders how to situate this narrative in its proper temporal space:

And where does that story begin? On the morning she ran off? On the day that we walked into the hotel lounge and found Jeremy Pendleton? Or does it begin twenty years before that... (pp. 185-186)

when she first met and fell in love with Jeremy? The time that Grace lost in her marriage to George when she still yearned for Jeremy shaped her story and that of Iris's accident, even as it is impossible to impose a rigid narrative chronology with a clear beginning, middle and end onto their experiences. The stroke means that Grace runs out of time to tell her story, elusive as it may be. Iris, however, pieces the fragments together and is left with a profound sympathy for her mother, 'for the impossible choices that people have to make, for the intractability of time and regret' (p. 319). In many ways, it is the conventional insistence on linear time rather than time itself that proves to be so intractable. Grace and Iris end up coming full circle with Iris taking her stroke addled mother back to the Drakensberg where the accident happened. At the start of the novel, Iris recalls how 'Grace remade her, after her accident. Reconstructed all her memories, taught her to walk, to talk, to read, to think' (p. 15). After the stroke, Grace is unable to perform even basic tasks for herself and, with Jess away; Iris is left to take care of her. In a rare moment of lucidity, she apologises to Iris with the words: 'I'm not much good to you now, am I...' (p. 323). Grace's existence now resembles what Wallace (2006:44) refers to as the 'second childhood' which implies that 'old age is a period of increasing dependence on others for basic bodily functions which suggests a circular rather than linear life pattern, culminating in a return to ma(t)ter'. Like Iris after her accident, coherent speech mostly eludes Grace after the stroke and Iris sees her mother in the hospital bed as she 'calls out unintelligibly, moans and thrashes' (p. 40). Despite Grace's compromised linguistic faculties, however, she and Iris reconnect at a very profound level when Iris finally learns to forgive herself and her mother and meets her mother in the spaces they are occupying on their circular temporal trajectories rather than relentlessly trying to excavate the past.

\section{Conclusion}

Winterson (1992:81) contends that, '[w]ritten on the body is a secret code only visible in certain lights; the accumulations of a lifetime gather there'. The characters of Ella, Marubani, Grace and Iris all, in various ways, carry the corporeal evidence of their traumatic gendered life experiences in their bodies and these bodily narratives remain hidden from plain sight, which causes much of the tension the characters struggle with in the novels. An important part of their struggles can be traced back to their futile attempts to slot their narratives into a linear, chronological temporal pattern that deals with the past in the present in order for them to move forward into their futures. Trauma, however, causes temporal dislocations which disrupt conventional understandings of time, chronology and linearity. In her discussion of literary texts, Rodi-Risberg (2015:44) notes how an author can make 'history present in the body of [a] character' and she explains that the 'temporal rupture' (p. 45) caused by traumatic experiences remains located in specific bodies even as they disrupt 'linear and sequential narratives' (p. 45). Milojevic (2008:333) calls for a re-invention of time because, she argues, the prevailing understandings of 'hegemonic time' refer to a social construct, that is, 'western, Christian, linear, abstract, clock dominated, work oriented, coercive, capitalist, masculine and anti-natural'. Although Milojević may be guilty of somewhat overstating her case, conventional notions of time do fail to speak to the gendered experiences of my selected female characters in general, and traumatised female characters in particular. This failure can, at least partially, be ascribed to the denial of the ways in which temporal dynamics play out on the bodies of women and how these bodies retain and speak traumatised experiences in ways that defy abstract, linear and masculine hegemonic time. Even as the female characters in my selected texts seek to 'unravel time' (Pitt 2015:185) so that they can find ways to make sense of their experiences, they are repeatedly reminded that their options are always already circumscribed by the expectations that are dictated by the mere fact that they are 'girls of their time'.

\section{Acknowledgements Competing interests}

The author declares that he has no financial or personal relationships which may have inappropriately influenced him in writing this article.

\section{References}

Apter, E., 2010, 'Women's time in theory', differences: A Journal of Feminist Cultural Studies 21(1), 1-18. https://doi.org/10.1215/10407391-2009-013

Bayer, B. \& Malone, K., 1996, 'Feminism, psychology and matters of the body', Theory and Psychology 6(4), 667-692. https://doi.org/10.1177/0959354396064007

Berg, S., 2006, 'Everyday sexism and posttraumatic stress disorder in women: A correlational study', Violence Against Women 12(10), 970-988. https://doi. org/10.1177/1077801206293082

Berger, J., 1997, 'Trauma and literary theory', Contemporary Literature 38(3), 569-582. https://doi.org/10.2307/1208980

Boehmer, E., 2015, The shouting in the dark, Sandstone Press, Dingwall, Scotland

Butler, J., 1990, Gender trouble: Feminism and the subversion of identity, Routledge, London.

Caruth, C., 1995, 'Trauma and experience: Introduction', in C. Caruth (ed.), Trauma: Explorations in memory, pp. 3-12, The John Hopkins University Press, London.

Culbertson, R., 1995, 'Embodied memory, transcendence, and telling: Recounting trauma, re-establishing the self', New Literary History 26, 169-175. https://doi. org/10.1353/nlh.1995.0007 
Derrida, J., 2000, Demeure: Fiction and testimony, transl. E. Rottenberg, Stanford University Press, Stanford.

Felman, S., 1992, 'Camus' the plague, or a monument to witnessing', in S. Felman \& D. Laub (eds.), Testimony: Crises of witnessing in literature, psychoanalysis, and history, pp. 93-119, Routledge, London.

Kennedy, R. \& Wilson, J.T., 2003, 'Constructing shared histories: Stolen generations testimony, narrative therapy and address', in J. Bennett \& R. Kennedy (eds.), World memory: Personal trajectories in global time, pp. 119-139, Palgrave Macmillan, New York.

Kilby, J., 2002, 'Redeeming memories: The politics of trauma and history', Feminist Theory 3(2), 201-210. https://doi.org/10.1177/1464700102003002345

Laub, D., 1992, 'Bearing witness or the vicissitudes of listening', in S. Felman \& D. Laub (eds.), Testimony: Crises of witnessing in literature, psychoanalysis and history, pp. 57-74, Routledge, London.

Meinig, S., 2004, Witnessing the past: History and post-colonialism in Australian historical novels, Gunter Narr Verlag, Tubingen.

Milojevíc, I., 2008, 'Timing feminism, feminising time', Futures 40, 329-345. https:// doi.org/10.1016/j.futures.2007.08.008

Mohale, M., 2016, The yearning, Picador Africa, Johannesburg.
Murphy, S.J., 2006, 'Past irony: Trauma and the historical turn', in Fragments and the swimming-pool library, viewed 27 February 2006, from http://www.manchester universitypress.co.uk/information_areas/journals/lit_history/130058.pdf

Nadal, K., Hamit, S., Lyons, O., Weinberg, A. \& Corman, L., 2013, 'Gender microaggressions: Perceptions, processes, and coping mechanisms of women', in M. Paludi (ed.), Psychology for business success, pp. 193-220, Praeger, Oxford.

Odih, P., 1999, 'Gendered time in the age of deconstruction', Time \& Society 8(1), 9-38. https://doi.org/10.1177/0961463X99008001002

Pitt, B., 2015, Notes from the lost property department, Penguin, Cape Town.

Rodi-Risberg, M., 2015, 'Trauma, temporality, and testimony in Carolivia Herron's Thereafter Johnnie', paper presented at the 22nd AISNA Biennial international conference, EUT Edizioni Università di Trieste, viewed 20 December 2016, from http://www.openstarts.units.it/dspace/handle/10077/11625

Smith, J., 2013 [1989], Misogynies, Westbourne Press, London.

Van der Merwe, C. \& Gobodo-Madikizela, P., 2007, Narrating our healing: Perspectives on working through trauma, Cambridge Scholars Publishing, Newcastle.

Wallace, D., 2006, 'Women's time: Women, age, and intergenerational relations in Doris Lessing's The diaries of Jane Somers', Studies in the Literary Imagination 39(2), 43-59. Winterson, J., 1992, Written on the body, Vintage Books, New York. 